\title{
Epidemiology and Management of Fusarium Wilt of China Asters
}

Wade H. Elmer, the Connecticut Agricultural Experiment Station, P.O. Box 1106, New Haven, CT 06504; and Robert J. McGovern, NBD Research Co., Ltd., Lampang, Thailand, 52000

\begin{abstract}
The epidemiology and strategies for management of Fusarium wilt of China aster (Callistephus chinensis) were studied in Connecticut and Florida, USA, by examining seed contamination, on-farm disease incidence, sanitation, host resistance, and various soil treatments. Five out of 25 commercial seed packages from three separate distribution companies assayed in Connecticut had seeds contaminated with the pathogen Fusarium oxysporum f. sp. callistephi. Farm surveys of two cutflower farms in Connecticut had disease incidences of 32 and 58\%, while in Florida, the incidence of the disease ranged from 0.002 to $71.2 \%$ in two cut-flower operations. All pathogenic isolates from seed and symptomatic plants in Connecticut were vegetatively compatible, suggesting a common origin. Pathogenic isolates from Florida and nonpathogenic isolates fell into different vegetative compatibility
\end{abstract}

Abstract

Elmer, W. H., and McGovern, R. J. 2013. Epidemiology and management of Fusarium wilt of China asters. Plant Dis. 97:530-536.

groups and may have had another origin. Sodium hypochlorite solutions $(1 \%)$ eliminated the fungus from seeds and Styrofoam when applied as a soak or spray, respectively. Soil fumigation with methyl bromide + chloropicrin, 1,3-dichloropropene + chloropicrin, or metam sodium maintained Fusarium wilt at low levels at a Florida cut-flower production facility. Evaluations of disease resistance of 44 cultivars in the greenhouse identified eight cultivars with moderate resistance. Four cultivars were identified with moderate resistance in field trials and thus could serve as a source of resistant germplasm for future breeding programs. These findings should encourage growers to use sanitation protocols to prevent entry of the pathogen into their fields and to choose commercially available cultivars that have moderate resistance.
The China aster (Callistephus chinensis (L.) Nees.) has long been valued for its brilliant flowers and diverse variety of sizes and shapes. Its preferred use in many ceremonies and festivals has assured its cultivation by many cultures. In India, China asters have become so valuable in festivals that over 6,000 tons of China asters were reportedly grown and sold in 2000 alone (2).

A wilt disease of China asters was first observed in the United States by Galloway (11), who, along with other scientists, associated Fusarium species with the wilt $(5,32)$. However, 22 years would pass before Beach (4) identified the causal fungus as Fusarium conglutinans v. callistephi and completed Koch's postulates. Since then, many synonyms were assigned to the China aster wilt pathogen, such as Fusarium conglutinans v. majus, Fusarium laterium v. frutigenum, and Fusarium oxysporum $(3,13,28,29)$. In the $1940 \mathrm{~s}$, the name $F$. oxysporum $\mathrm{f}$. sp. callistephi, was adopted (31). No races have been documented, but they likely exist. Although there has been speculation that other Fusaria could cause the disease, this has not been substantiated (3).

Sanitation has been shown to be an essential strategy against Fusarium wilts (9). From the very first report of Fusarium wilt of China aster, the pathogen was suspected to be associated with seed debris (4). Orlicz-Luthardt (25) showed the pathogen could be recovered at a low incidence $(<1 \%)$ from contaminated seeds. We also speculated that a severe outbreak of the disease in a Florida cut-flower facility in 2001 was most likely caused by the use of contaminated seed. Although many effective seed sterilization procedures were developed, many employed toxic mercurial compounds, which are not in use today $(3,29)$. Alternate methods, such as microwaving, were found to decrease seed viability (12), but soaks in diluted (1 to $10 \%) \mathrm{NaOCl}$ solutions worked well in our laboratory for many types of seeds (10). The incidence of $F$. oxysporum f. sp. callistephi on commercial China aster seed today is not known, and this lack of awareness highlights large gaps in

Corresponding author: Wade H. Elmer, E-mail: Wade.Elmer@ct.gov

Accepted for publication 16 October 2012.

http://dx.doi.org/10.1094/PDIS-05-12-0445-RE

(C) 2013 The American Phytopathological Society understanding the epidemiology and rapid spread of this disease. In the United States, it is not known if seed contamination is the primary source of the pathogen found in commercial fields.

The genetic relatedness of plant-pathogenic isolates can provide useful epidemiological information as to possible origins of the inoculum and mode of movement. Although molecular assays, such as amplified fragment length polymorphisms or sequenced gene products, are more informative in understanding diversity, simple tests for vegetative compatibility using nitrate-nonutilizing (Nit) mutants (6) can address whether seed isolates are closely related to field isolates.

Commercial production of ornamentals, including China aster, often starts in a transplant or "plug" tray. These containers have a relatively high structural integrity which facilitates their reuse Therefore, many growers reuse these transplant trays, especially those made of Styrofoam. We observed that reused Styrofoam transplant trays can be a source of initial inoculum for epidemics of Fusarium spp. (20,22). In fact, F. oxysporum f. sp. callistephi was detected in wilting China aster transplants from a commercial producer that routinely reused trays without prior disinfestation (R. J. McGovern, unpublished data). Steam disinfestation of trays is highly effective, but may not be economically feasible for all plant production operations. Limited data currently exist on other disinfestation alternatives, such as chemicals, that are effective against Fusarium spp.

Finding a replacement for the preplant fumigant methyl bromide is a dilemma faced by many growers in the United States, including those who produce cut flowers. Under the Montreal Protocol on Substances that Deplete the Ozone Layer (1) and the U.S. Clean Air Act (33), methyl bromide was phased out in 2005 in the United States except for critical use exemptions. Currently, California and Florida cut-flower growers have an exemption from the phase-out to use methyl bromide in control of moderate to severe soilborne pathogen infestations (30). However, it is likely that the diminishing availability of methyl bromide, coupled with its increasing cost, will force growers to seek soil disinfestation alternatives. We are not aware of any research evaluating alternatives to methyl bromide for management of soilborne pathogens of China aster.

During the 1920s, breeding efforts in Wisconsin, USA, produced several resistant lines that were developed from commercial China aster varieties (15). However, the emergence of new races of the 
pathogen from Japan overcame the resistance. Over the next few decades, all resistant cultivars became susceptible to new strains of the pathogen. Researchers became convinced that durable lasting resistance would be difficult to achieve (29). As reported by Baker (3), a despondent seedsman claimed "Asters today are at their lowest ebb...." Since then, many laboratories have developed breeding programs in an attempt to develop resistant lines suitable for their industries $(24,26)$. To our knowledge, an evaluation of cultivar resistance has not been done in the United States since the 1950s (3).

The objectives of this research were to determine the level of incidence of $F$. oxysporum f. sp. callistephi in commercial seed packages and potential for spread to the field, the relatedness of isolates of the pathogen on commercial seed and from isolates collected from the field, the effect of sanitation and fumigation practices on suppression of Fusarium wilt of China aster, and to assess the level of resistance in commercial cultivars to the pathogen in the greenhouse and field.

\section{Materials and Methods}

Incidence and relatedness of $F$. oxysporum f. sp. callistephi on seeds and in commercial fields. Two production groups were surveyed at a commercial cut-flower production site in West Central Florida (Punta Gorda) 1 month after planting. The first group was planted from $02 / 19 / 01$ to $03 / 19 / 01$ and the second group from 03/29/01 to 04/10/01. Two to four beds of eight China aster cultivars were surveyed for the incidence of Fusarium wilt; each bed consisted of about 2,100 plants. For disease incidences $<10 \%$, the percentage of symptomatic plants within a bed was visually estimated. Representative samples of wilting plants were taken to the lab for determination of infection by F. oxysporum using Komada's selective medium (KSM) (17) and the techniques indicated below. A commercial flower field in southern Connecticut (North Branford) and one in southeastern Connecticut (Gales Ferry) were both visited in August 2004 and again in 2005. Both plantings had approximately 100 to 200 plants and were planted with transplants in June. Both farms practiced rotation with vegetables. Ten stunted, wilted China aster plants were removed each year. Pieces $(0.5 \mathrm{~cm})$ of discolored vascular tissue from the base of the stems were surface-disinfested in $0.53 \% \mathrm{NaOCl}$, rinsed in tap water, and placed on KSM. Cultures were incubated at room temperature for 5 days. Single conidia from each colony that grew from seed were subcultured onto carnation leaf agar (CLA) (18). Cultures of $F$. oxysporum were identified based on spore morphology and stored on silica gel (18).

Twenty-five commercial seed packages were purchased in 2003 from three different seed distribution companies: Hart Seed Company (Wethersfield, CT), Johnny's Selected Seeds (Winslow, ME), and Harris Seeds (Rochester, NY). Seed packages were opened and 100 seeds were immediately placed onto KSM, which is selective for $F$. oxysporum (25 seeds/plate). Eighteen isolates of $F$. oxysporum were obtained. In addition, seven single-spore isolates of $F$. oxysporum were recovered from seeds of 'Matsumoto Light Blue' in Florida (see below for details), and one isolate (0-1085) was obtained from the Fusarium Research Center (FRC) (Pennsylvania State University, University Park). Isolates were assayed for pathogenicity on China aster 'Lilliput Blue Moon' (Thompson \& Morgan Co., Jackson, NJ). Each test isolate was grown on twice-autoclaved millet (50 g millet $/ 50 \mathrm{ml}$ distilled water) in $100 \mathrm{ml}$ in Erlenmeyer flasks for 2 weeks, and air-dried. Ten grams of colonized millet was mixed into 2 liters of Pro-Mix BX potting mix (Premier Horticulture, Inc., Quakertown, PA) and dispensed into seven $250-\mathrm{cm}^{3}$ plastic pots. Pots were planted with 3 -week-old seedlings, set on greenhouse benches, and watered as needed for 1 month. Temperature set points were $17^{\circ} \mathrm{C}$ at night and $22^{\circ} \mathrm{C}$ during the day. Venting occurred at $25^{\circ} \mathrm{C}$. Plants were rated for disease 6 weeks later based on the 1 to 5 scale: $1=$ no disease, $2=$ stunting, $3=$ badly stunted, $4=$ wilting, and $5=$ dead. Isolates were rated as pathogens if they caused a mean disease rating $>2.0$. The pathogen was reisolated from symptomatic plants, but was not recovered from control plants.
Relatedness between the field isolates and the seed isolates was examined using vegetative compatibility tests. Complementary nit mutant pairs (NitM and nit 1 or NitM and nit3) were generated as previously described (6). Pairings were conducted on minimal media. Wild type growth at the point of anastomosis was considered as evidence of vegetative compatibility and used to assign isolates into vegetative compatible groups (VCGs). Pairings were done twice.

Evaluation of sanitation for management of $F$. oxysporum $f$. sp. callistephi. Two experiments were conducted to evaluate the effectiveness of $\mathrm{NaOCl}$ as a seed disinfestant for $F$. oxysporum $\mathrm{f}$. sp. callistephi. Two hundred seeds of China aster 'Matsumoto Light Blue' (Stokes Seed Co.) were shown in preliminary testing to be approximately $12 \%$ infested with $F$. oxysporum. Seeds were soaked for $30 \mathrm{~min}$ in either a $0.053 \% \mathrm{NaOCl}$ solution $(1 \%$ household bleach) or sterile, distilled water (control). The seeds were triple-rinsed and blotted dry on paper towels. Half of the treated and control seeds were immediately placed onto KSM (nine seeds per plate). An equal number of seeds were placed on moistened filter paper in glass dishes. Plates were incubated at $28^{\circ} \mathrm{C}$. After 10 days, the numbers of $F$. oxysporum colonies and germinated seedlings were counted.

Experiments were also conducted to compare the ability of different treatments to disinfect Styrofoam. An isolate of $F$. oxysporum f. sp. callistephi from China aster seed (01-1852-A) was grown on acidified CLA for 7 days to produce conidia. The conidia were harvested in sterile, distilled water, and the suspension was standardized to 10 conidia/ml. Styrofoam sheets $(1.3 \mathrm{~cm}$ thick) were cut into $8.25-\mathrm{cm}$-diameter discs. The discs were dipped for 10 $\mathrm{s}$ in the conidial suspension, shaken to remove excess water, and blotted dry for $3 \mathrm{~s}$ using a sterile paper towel. Each disc was then treated with the appropriate chemical and incubated for 5 days at $26^{\circ} \mathrm{C}$ on KSM. The resulting Fusarium colonies were counted. Each treatment was replicated using 18 Styrofoam discs in each of three tests per experiment. Disinfestation chemicals were sprayed on the discs until runoff and then the discs were air-dried. Treatments included: sterile, deionized water, $0.053 \% \mathrm{NaOCl}$, Zerotol (1:300 solution; Biosafe Systems, L.L.C., East Hartford, CT), ethanol (70\% solution; Fisher Scientific, Pittsburgh, PA), Lysol Disinfectant Spray (full strength; Rickitt Benckiser PLC, Berkshire, UK), Physan 20 (4 ml/liter; Maril Products Inc., Tustin, CA), and peroxyacetic acid (1:100 solution; Phyton Corporation, Edina, $\mathrm{MN})$. A noninoculated control (Styrofoam discs dipped in sterile, deionized water then air-dried) and an inoculated control (Styrofoam discs dipped in the conidial suspension of $F$. oxysporum then air-dried) were also included in the experiments. The experiment was conducted twice.

In 1998, an experiment to evaluate methyl bromide alternatives was conducted during the growing season at a 50-year-old commercial cut-flower production facility in West Central Florida. The site consisted of Immokalee-Myakka fine sand, was grown in China aster year-round, and had a history of both Fusarium wilt and root-knot nematodes (Meloidogyne sp.). The experiment compared the effectiveness of 1,3-dichloropropene plus chloropicrin (Telone C-17, Dow AgroSciences LLC, Indianapolis, IN, 54 liters/ha, applied by means of soil-injection) and metam sodium (Vapam HL, AMVAC, Los Angeles, CA, 152 liters/ha, applied through two drip tapes buried $15.2 \mathrm{~cm}$ below the soil surface) with methyl bromide plus chloropicrin (Brom-O-Gas 2\%, Great Lakes Chemical Corp., West Lafayette, IN, $110 \mathrm{~kg} / \mathrm{ha}$, applied by means of soil-injection) in suppressing Fusarium wilt and root-knot nematodes in China aster. The grower did not wish to include a nontreated control because of the high risk of disease. Fumigants were applied to 0.91-m-wide raised beds which were covered by black, low-density polyethylene mulch. The experiment was replicated over time; the same fumigants were used in the same plant beds prior to four successive plantings of China aster 'Matsumoto Blue.' Fumigants were applied on 26 September 1998, 14 January 1999, 22 December 1999, and 15 August 2000. Fields were planted approximately 2 weeks later with transplants. The number of 
dead/wilted plants per 1,750-plant bed was counted 1 month after planting, and representative symptomatic plants were processed for recovery of F. oxysporum on KSM as indicated above and for other soilborne fungi using acidified $25 \%$ potato dextrose agar.

Evaluation of commercial China aster cultivars for resistance to Fusarium wilt. Seeds of 45 cultivars of China aster were obtained from six seed distribution companies in 2005. Seeds were agitated in $0.535 \% \mathrm{NaOCl}$ plus one drop of Tween 20 (Cayman Chemical Co., Ann Arbor, MI) for $1 \mathrm{~min}$ to eliminate pathogens, thoroughly rinsed, and germinated in 36-cell pack trays filled with Pro-Mix BX potting mix. We had found that $1 \mathrm{~min}$ exposure to $0.53 \% \mathrm{NaOCl}$ was equivalent to a 30 -min soak in $0.05 \%$. One seedling from each cultivar was placed in a $10-\mathrm{cm}$-diameter pot filled with potting mix infested with millet inoculum prepared as above except that the millet was ground in a Wiley mill prior to inoculation with the pathogen. Millet was colonized by $F$. oxysporum $\mathrm{f}$. $\mathrm{sp}$. callistephi (isolate JD4) and added at $1 \mathrm{~g}$ millet inoculum/liter potting mix. An equal number of plants were transplanted into noninfested potting mix to serve as controls. There were nine replications of one plant per pot. Pots were arranged on greenhouse benches in a randomized block design. Plants were irrigated as needed and treated once with a fertilizer solution containing a 15-4-15 (N-P-K) fertilizer at $300 \mathrm{ppm}$ N. Greenhouse temperatures were set at $18^{\circ} \mathrm{C}$ for heating and $23^{\circ} \mathrm{C}$ for ventilation under ambient light. Six weeks after inoculation, plants were rated on a disease severity scale as described above. Fresh and dry weights of aboveground portions were recorded. The experiment was repeated in 2006 using the same seed lot.

Field studies were done in 2005 on a Watchaug fine sandy loam $(\mathrm{pH}=5.9)$ in Hamden, CT and in Windsor, CT on a Wethersfield fine loamy sand $(\mathrm{pH}=6.7)$. The fields were plowed mid-May, and 6-mil black plastic was laid down 25 May and 1 June. Eight cultivars of China aster were selected based on greenhouse tests in addition to seeds of six susceptible cultivars and two untested cultivars to make a total of 16 cultivars in each trial. Seeds were surface-sterilized and germinated as previously described. Seedlings were thinned to one seedling per cell. Half of the plants for each cultivar were drenched with $10^{4}$ conidia/ml of $F$. oxysporum $\mathrm{f}$. sp. callistephi $(25 \mathrm{ml} /$ cell) before planting; the other half received an equal volume of water (controls). The inoculum was produced from isolate JD4 by culturing it on potato-carrot agar (7) for 10 days at $25^{\circ} \mathrm{C}$, washing conidia from the plate, and adjusting to concentration.

Plots $0.3 \mathrm{~m}$ long and $0.9 \mathrm{~m}$ apart were each planted with five plants on 26 May and 1 June. A split plot design was used where the main plot was inoculation and subplots were cultivars. Each cultivar/inoculation was replicated four times. Plots were fertilized on 28 June with $340 \mathrm{~kg} / \mathrm{ha}$ of $10-10-10$, N-P-K fertilizer. Plots were irrigated as needed to provide $2.5 \mathrm{~cm} /$ week. Each plant in each plot was rated for disease severity on a scale of 1 to 5 , where $1=$ no disease, 2 = slight yellowing, $3=$ yellowing and slight wilt, $4=$ severe wilt, and $5=$ dead. Marketable flowers were collected and counted on 15 July, 25 July, and 5 August, and counts were summed. The mean disease severity values of plants in inoculated plots were compared with their respective controls using Tukey's test at $P=0.05$.

Statistical analysis. Experimental repetitions of each experiment were analyzed by testing for interactions between repetition and treatments using ANOVA (Systat 13, Chicago, IL). When no interactions occurred, data sets for each variable were combined. Field plots were analyzed using split plot design. Pathogenicity tests and cultivar evaluations were separated using Bonferroni's test at $P=0.05$. Pearson correlation coefficients were computed when needed. Evaluation of disinfestants and fumigants was analyzed using ANOVA followed by mean separation by Duncan's multiple range test and Fisher's protected LSD, respectively, at $P=$ 0.05 (SAS Institute, Cary, NC).

\section{Results}

Incidence and relatedness of $F$. oxysporum $\mathrm{f}$. sp. callistephi in commercial fields and on seeds. Fusarium wilt incidence in different blocks of China asters at two West Central Florida cutflower production farms in 2001 ranged from 0.002 to $71.2 \%$ and was severe at both sites. The major cultivars in these planting groups were 'Kurenai Dark Scarlet,' 'Matsumoto Light Blue,' and 'Matsumoto Pink' (Table 1). F. oxysporum was consistently isolated from symptomatic plants sampled in both planting groups. In North Branford, CT, the planting had an incidence of $32 \%$ wilt based on 200 plants, and in Gales Ferry, CT, the incidence was $58 \%$ based on 100 plants. Fusarium spp. were isolated from each of the 10 symptomatic stems removed from the two commercial flower fields in CT $(n=20)$ (data not shown). All colonies of Fusarium spp. originating from single spores were identified on CLA as F. oxysporum.

F. oxysporum was also isolated from two seed lots of China aster 'Matsumoto Light Blue' in Florida at a mean incidence of $12.2 \%$ (data not shown). Of the seven Florida isolates subsampled from the seed isolates and tested for pathogenicity, four isolates produced mean disease ratings greater than 2.0 (Table 2). In Connecticut, out of 25 seed packages, $F$. oxysporum was isolated from seven (28\%) different packages. Incidence was low (1 to 3\%) in all packages except for one package ('Pinocchio mix') that had an incidence of $8 \%$. Pathogenicity tests on the 18 seed isolates from the seven Connecticut seed packages revealed that 13 isolates from

Table 1. Incidence of Fusarium wilt in China aster in a commercial cut-flower production facility in West Central Florida, 2001

\begin{tabular}{|c|c|c|c|c|c|}
\hline \multirow[b]{2}{*}{ China aster cultivar } & \multicolumn{5}{|c|}{ Fusarium wilt incidence (\%) } \\
\hline & $\operatorname{Bed} 1^{\mathrm{a}}$ & Bed 2 & Bed 3 & Bed 4 & Average (\%) \\
\hline \multicolumn{6}{|l|}{ Planting date $02 / 19 / 01$} \\
\hline Kurenai Dark Scarlet & 75 & 60 & 60 & 90 & 71.2 \\
\hline Matsumoto Scarlet & 1.2 & 2.8 & 1.2 & 1.0 & 1.5 \\
\hline Matsumoto Pink & 11.1 & 25 & 2.5 & 0.8 & 9.8 \\
\hline Matsumoto Rose & 0.4 & 1.0 & 1.0 & 0.2 & 0.6 \\
\hline Matsumoto Salmon & 2.2 & 0.8 & $\ldots$ & $\ldots$ & 0.8 \\
\hline Rainbow Mix & 0.1 & 0.1 & $\ldots$ & $\ldots$ & 0.05 \\
\hline Matsumoto White & 0.7 & 2.0 & 0.8 & $\ldots$ & 2.4 \\
\hline Matsumoto Light Blue & 1.8 & 9.9 & 45 & 20 & 19.2 \\
\hline Average for $02 / 19 / 01-03 / 19 / 01$ & & & & & 6.0 \\
\hline \multicolumn{6}{|l|}{ Planting date $03 / 29 / 01$} \\
\hline Kurenai Dark Scarlet & 30 & 40 & 25 & 20 & 28.8 \\
\hline Matsumoto Scarlet & 0.0 & 0.01 & 0.0 & 0.0 & 0.002 \\
\hline Matsumoto Pink & 2.0 & 1.1 & 6.6 & 25 & 8.6 \\
\hline Matsumoto Rose & 0.0 & 1.0 & $\ldots$ & $\ldots$ & 0.02 \\
\hline Matsumoto Salmon & 0.0 & 0.8 & 15 & $\ldots$ & 5.2 \\
\hline Rainbow Mix & 0.0 & 0.8 & $\ldots$ & $\ldots$ & 0.2 \\
\hline Average for $03 / 29 / 01-04 / 10 / 01$ & & & & & 7.1 \\
\hline
\end{tabular}

${ }^{\mathrm{a}}$ Each bed consisted of about 2,100 plants. 
five different seed packages had disease ratings greater than 2.0. These isolates were designated as $F$. oxysporum f. sp. callistephi. Of the 21 stem isolates from Connecticut, pathogenicity tests were performed on nine isolates, whereupon seven were found to be pathogenic and were labeled as $F$. oxysporum f. sp. callistephi (Table 2).

Vegetative compatibility tests on 47 isolates revealed that there was one large VCG (VCG $1, n=33$ ) that contained all the pathogens that were isolated from seed in Connecticut $(n=14)$ (Table 2). This VCG also contained all of the isolates recovered from infected stems $(n=18)$ collected in Connecticut along with the FRC isolate (O-1085) and one isolate (22-2) from seed that was designated as a nonpathogen. Another VCG (VCG 2, $n=3$ ) was identified among the isolates from Florida along with two pathogenic isolates that would not form heterokaryons with any other VCG or isolate. Nonpathogenic isolates fell into mostly single-member VCGs.

Evaluation of sanitation for management of $F$. oxysporum $f$. sp. callistephi. The two seed lots of China aster 'Matsumoto Light Blue' were bulked to yield a mean incidence of $12.2 \%$ of $F$. oxy- sporum when placed on KSM (17), but when seed was treated with $0.053 \% \mathrm{NaOCl}, F$. oxysporum was not detected. Seed germination was unaffected by treatment with the disinfectant (data not shown).

In the first experiment, all treatments including the sterile water spray significantly reduced the number of Fusarium colonies recovered from the Styrofoam discs compared with the inoculated control. However, only $\mathrm{NaOCl}$, Lysol, and peroxyacetic acid reduced the fungus to an undetectable level (Fig. 1). In experiment 2, all treatments except the sterile water spray reduced recovery of Fusarium from the discs (Fig. 2). However, only $\mathrm{NaOCl}$ reduced the fungus to an undetectable level. Zerotol was intermediate in effectiveness compared with the rest of the chemical treatments. The sterile water spray increased the colony count of Fusarium. This increase may have resulted from a combination of less forceful removal and higher residual wetness leading to increased conidial germination.

Six weeks after fumigation, dead/wilted plants were detected at low incidences $(<1.0 \%)$ with all treatments. Out of 1,750 plants in four production cycles, we observed an average incidence of $0.6 \%$

Table 2. Origin, pathogenicity, and vegetative compatibility of Fusarium oxysporum isolates from symptomatic plants and seeds of China asters

\begin{tabular}{|c|c|c|c|c|c|c|}
\hline Isolate code & Tissue & Cultivar & State of origin & Disease ratinga $^{\mathbf{a}}$ & Pathogenic $^{b}$ & $V_{C G}{ }^{c}$ \\
\hline 0118521 & Seed & Matsumoto Light Blue & FL & 2.9 & Yes & 2 \\
\hline 0118522 & Seed & Matsumoto Light Blue & FL & 1.1 & No & Single \\
\hline 0118523 & Seed & Matsumoto Light Blue & FL & 3.6 & Yes & Single \\
\hline 0118524 & Seed & Matsumoto Light Blue & FL & 1 & No & Single \\
\hline $011852 \mathrm{~A}$ & Seed & Matsumoto Light Blue & FL & 3.8 & Yes & 2 \\
\hline $011852 B$ & Seed & Matsumoto Light Blue & FL & 1.6 & No & 2 \\
\hline $011852 \mathrm{C}$ & Seed & Matsumoto Light Blue & FL & 3.6 & Yes & Single \\
\hline 15 & Seed & Serenade Mix & $\mathrm{CT}$ & 1.0 & No & Single \\
\hline $3-1$ & Seed & Matsumoto Formula mix & $\mathrm{CT}$ & 4.3 & Yes & 1 \\
\hline $8-1$ & Seed & Matsumoto Formula mix & CT & 1.0 & No & Single \\
\hline 1510 & Seed & Dwarf Queen & $\mathrm{CT}$ & 3.1 & Yes & 1 \\
\hline 154 & Seed & Dwarf Queen & CT & 2.0 & No & Single \\
\hline 158 & Seed & Dwarf Queen & CT & 2.9 & Yes & 1 \\
\hline 161 & Seed & Pinocchio mix & $\mathrm{CT}$ & 4.1 & Yes & 1 \\
\hline 1613 & Seed & Pinocchio mix & CT & 4.7 & Yes & 1 \\
\hline 164 & Seed & Pinocchio mix & CT & 3.4 & Yes & 1 \\
\hline 165 & Seed & Pinocchio mix & CT & 2.7 & Yes & 1 \\
\hline 169 & Seed & Pinocchio mix & CT & 3.7 & Yes & 1 \\
\hline $16-14$ & Seed & Pinocchio mix & CT & 3.9 & Yes & 1 \\
\hline $16-15$ & Seed & Pinocchio mix & CT & 3.0 & Yes & 1 \\
\hline $16-2$ & Seed & Pinocchio mix & CT & 2.3 & Yes & 1 \\
\hline $20-4$ & Seed & Lillput Blue moon & CT & 4.3 & Yes & 1 \\
\hline $22-1$ & Seed & Compliment & CT & 2.9 & Yes & 1 \\
\hline $22-2$ & Seed & Compliment & CT & 2.0 & No & 1 \\
\hline $23-2$ & Seed & Astoria Mix & $\mathrm{CT}$ & 1.8 & No & Single \\
\hline Ha1 & Stem & Field 2 Gales Ferry, CT & $\mathrm{CT}$ & $\ldots{ }^{\mathrm{d}}$ & $\ldots$ & 1 \\
\hline $\mathrm{Ha} 2$ & Stem & Field 2 Gales Ferry, CT & CT & $\ldots$ & $\ldots$ & 1 \\
\hline $\mathrm{Ha} 3$ & Stem & Field 2 Gales Ferry, CT & CT & $\ldots$ & $\ldots$ & 1 \\
\hline $\mathrm{Ha} 4$ & Stem & Field 2 Gales Ferry, CT & CT & $\ldots$ & $\ldots$ & 1 \\
\hline Ha5 & Stem & Field 2 Gales Ferry, CT & CT & 4.3 & Yes & 1 \\
\hline Ha6 & Stem & Field 2 Gales Ferry, CT & CT & $\ldots$ & $\ldots$ & 1 \\
\hline $\mathrm{Ha} 7$ & Stem & Field 2 Gales Ferry, CT & CT & $\ldots$ & $\ldots$ & 1 \\
\hline $\mathrm{Ha} 8$ & Stem & Field 2 Gales Ferry, CT & CT & $\ldots$ & $\ldots$ & 1 \\
\hline $\mathrm{Ha} 9$ & Stem & Field 2 Gales Ferry, CT & CT & $\ldots$ & $\ldots$ & 1 \\
\hline Jd1 & Stem & Field 1 Branford, CT & CT & 3.9 & Yes & 1 \\
\hline $\mathrm{Jd} 10$ & Stem & Field 1 Branford, CT & CT & 5 & Yes & 1 \\
\hline $\mathrm{Jd} 2$ & Stem & Field 1 Branford, CT & CT & 4.6 & Yes & 1 \\
\hline $\mathrm{Jd} 3$ & Stem & Field 1 Branford, CT & CT & 3.2 & Yes & 1 \\
\hline $\mathrm{Jd} 4$ & Stem & Field 1 Branford, CT & CT & 5.0 & Yes & 1 \\
\hline $\mathrm{Jd} 7$ & Stem & Field 1 Branford, CT & CT & 1.6 & No & 3 \\
\hline $\mathrm{Jd} 8$ & Stem & Field 1 Branford, CT & CT & 1 & No & 3 \\
\hline Jd9 & Stem & Field 1 Branford, CT & CT & 1 & No & Single \\
\hline $\mathrm{JdB}$ & Stem & Field 1 Branford, CT & CT & $\ldots$ & $\ldots$ & 1 \\
\hline $\mathrm{JdC}$ & Stem & Field 1 Branford, CT & CT & $\ldots$ & $\ldots$ & 1 \\
\hline $\mathrm{JdD}$ & Stem & Field 1 Branford, CT & CT & $\ldots$ & $\ldots$ & 1 \\
\hline $\mathrm{JdE}$ & Stem & Field 1 Branford, CT & CT & $\ldots$ & $\ldots$ & 1 \\
\hline O 1085 & Stem & Fusarium Research Center & PA & $\ldots$ & $\ldots$ & 1 \\
\hline Controls & $\ldots$ & & & 1 & $\ldots$ & $\ldots$ \\
\hline
\end{tabular}

\footnotetext{
a Plants were rated for disease 6 weeks later based on the 1 to 5 scale: $1=$ no disease, $2=$ stunting, $3=$ badly stunted, $4=$ wilting, and $5=$ dead.

${ }^{b}$ Isolates were rated as pathogens if they caused a mean disease rating $>2.0$.

c VCG = vegetative compatibility group.

d Not done.
} 
with methyl bromide + chloropicrin (98:2) (110 kg/ha, soil injection); $0.9 \%$ with 1,3-dichloropropene + chloropicrin (83:17) (54 liters/ha); and $0.8 \%$ with metam sodium (42\%) (152 liters, chemigation). F. oxysporum was consistently isolated from symptomatic asters. No appreciable losses of flower quality or number were noted.

Evaluation of commercial cultivars for resistance to Fusarium wilt. Both repetitions of the greenhouse cultivar trials gave similar results, so data were combined (Table 3 ). Wilt symptoms in the greenhouse began to show up 1 week after transplanting. Six weeks later, eight cultivars had disease ratings that did not statistically differ from their respective controls grown in noninfested soil. Four cultivars appeared yellow and stunted when grown in noninfested soil, but no Fusarium spp. were isolated from these plants. As a result, some of these plants received disease ratings greater than 2.0 that prevented a comparison with plants in infested soil. However, four cultivars ('Bouquet Powderpuff Mix,' Benary's 'Princess Formula Mix,' 'Finest Mixed,' and 'Matsumoto Formula Mix') had mean disease ratings $<2.0$. Twenty-four cultivars were rated as highly susceptible (disease rating $>4.0$ ), and the remaining 10 cultivars were ranked as being slightly to moderately susceptible. Dry weights were affected less by inoculation than were the disease ratings, but they followed a similar trend and were inversely correlated with disease ratings $(R=-0.71, P<0.001)$.

Field plots in Hamden, CT and in Windsor, CT had similar levels of disease, and the cultivars behaved similarly, so the data were combined. Symptoms of yellowing and wilt appeared 3 weeks after transplanting in both sites. We only considered cultivars with disease ratings $<2.0$ to have high resistance (Table 3), even though many cultivars had disease ratings that were greater than 2.0 but did not significantly differ from their noninfested controls. Cultivars that were resistant in greenhouse trials ('Bouquet Powderpuff Mix' [HS] and 'Astoria Mix' [SS and HS]) and 'Sandy Mix' (SS) along with one untested cultivar ('Aster composition' (SS) were considered to have moderate resistance. All of these cultivars had no significant reduction in marketable flowers when compared to plants in noninfested plots. Four other cultivars produced quantities of flowers that did not differ statistically from their controls, but had higher disease ratings. These cultivars had tolerance to Fusarium wilt. Disease ratings were inversely proportional to the number of marketable flowers $(r=-0.57, P=0.001)$.

\section{Discussion}

Fusarium wilt of China aster has plagued the U.S. cut-flower industry since it was first observed in 1896. Over the past century, a pattern has revealed a pathogen with a propensity for rapidly overcoming the resistance of the host. Given the difficulties that breeders have in identifying durable resistance and the demand for the

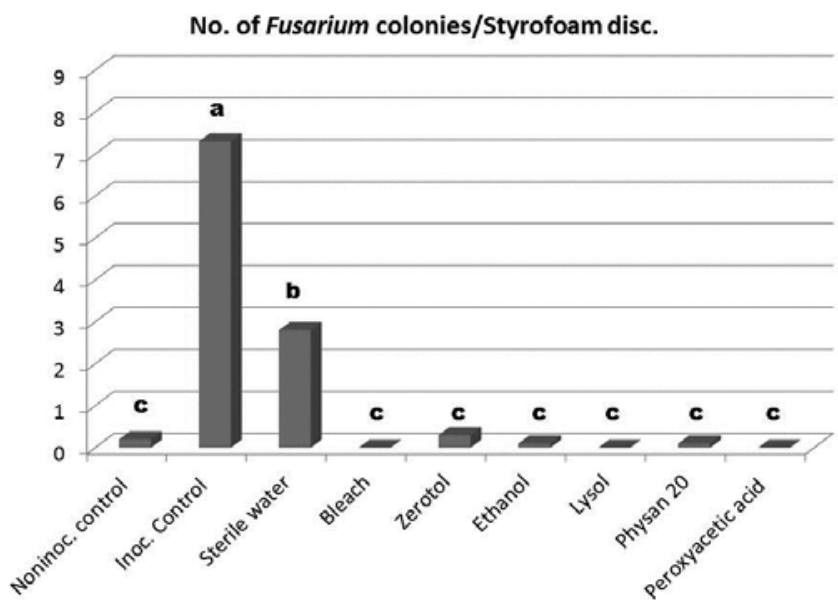

Fig. 1. Effect of disinfestants on recovery of Fusarium oxysporum f. sp. callistephi (experiment 1). Different letters indicate significant differences by Duncan's multiple range test at $P<0.05$. flower, it is not surprising that Fusarium wilt appears wherever China asters are grown.

Our first objective, to determine the level of incidence of $F$. oxysporum f. sp. callistephi on commercial seeds, was motivated by past studies that found the incidence relatively low (25). Outbreaks of the disease in Florida and Connecticut led us to wonder if greater incidence of the fungus had occurred on seed. Eighty percent of the seed packages had no F. oxysporum f. sp. callistephi associated with the seed. With the exceptions of 'Matsumoto Light Blue' in the Florida study with a mean incidence of $12.2 \%$ and 'Pinocchio Mix' in the Connecticut study that had $8 \%$, contamination was between 1 and $3 \%$. Our findings were in general agreement with those of Orlicz-Luthardt (25). These levels might be sufficient to cause major field epidemics resulting in significant crop loss. Low incidence would be expected to result in low transmission in the field that, in turn, may allow the pathogen to go unnoticed, and build up inoculum in the soil. Although given that these fields were in rotation, another possibility is that the pathogen rapidly spreads aerially from conidia that has been observed sporulating profusely on stems $(4,11,13,28,33)$. Aerial spread of Fusarium wilt has been observed on tomato and basil $(16,27)$. Scenarios have been documented on other crops where major Fusarium wilt epidemics were related to a low seedborne incidence $(<5 \%)(8)$. This highlights the importance of early scouting and roguing out wilted plants before they can become signficant sources of inoculum.

Despite the different sources of the isolates from seeds and plants, almost all pathogenic isolates were vegetatively compatible with each other. Although vegetative compatibility is not useful for assessing genetic variability in a population, it has utility in establishing relatedness among a group of isolates of the same species, i.e., compatible isolates are more likely to have the same progenitor than incompatible isolates. These findings suggest that a large, closely related population of $F$. oxysporum f. sp. callistephi is being distributed on seed and the same population is responsible for the epidemics observed in the Connecticut fields. This may be a result of seed distribution companies purchasing their seeds from one region or supplier. In this regard, it is possible that contaminated seed of China aster 'Matsumoto Light Blue' in Florida that had isolates in a smaller VCG came from a different source and have played a role in the epidemic of Fusarium wilt observed at the Florida cut-flower facility in 2001. Regardless of the source, these findings should encourage seed producers, distribution companies, and growers to develop and routinely practice disinfestation procedures prior to selling/planting China aster seed. A number of procedures are available for eliminating Fusarium spp. from seed (11). We demonstrated that soaking in $1.0 \% \mathrm{NaOCl}$ was very effective in eliminating $F$. oxysporum f. sp. callistephi from China

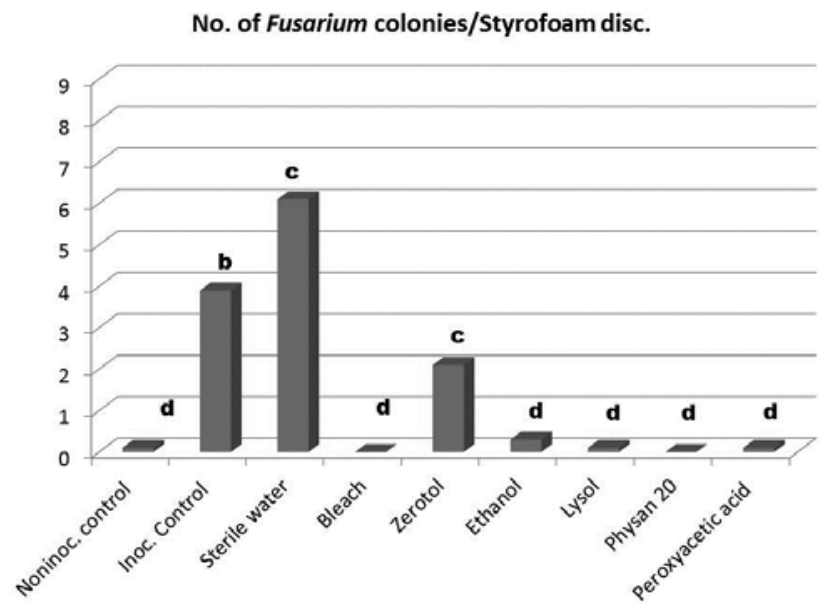

Fig. 2. Effect of disinfestants on recovery of Fusarium oxysporum f. sp. callistephi (experiment 2). Different letters indicate significant differences by Duncan's multiple range test at $P<0.05$. 
aster seed. This practice was subsequently adopted with great success by the Florida cut-flower grower who experienced significant losses from Fusarium wilt in 2001.

Sanitation, as a key element in plant disease management of flower crops, cannot be overemphasized. We have consistently observed significant losses resulting from use of propagative material (seeds, transplants, and tubers, etc.), production containers (transplant trays), and supports (stakes) contaminated with a number of Fusarium spp. including F. oxysporum (19,20,22,23; R. J. McGovern, unpublished). This research demonstrated that sprays of certain materials, particularly $\mathrm{NaOCl}$, were effective in reducing or eliminating $F$. oxysporum f. sp. callistephi from the surface of Styrofoam. It should be noted that the architecture of transplant trays may require a preliminary wash to remove debris coupled with a longer duration disinfestation including the use of total im- mersion. It may also be necessary to remove the disinfestant after treatment through rinsing to prevent phytotoxicity. Label recommendations for disinfestation must always be followed.

All three soil fumigants tested maintained equally low levels of F. oxysporum f. sp. callistephi at a Florida production site. It can be argued that the pathogen may have been suppressed by other factors including the environment and soil ecology. It is unlikely that this was the case given the previous and subsequent high incidence of Fusarium wilt at the site. Previous research in Florida indicated that Telone C-17 and Vapam were also effective in reducing Fusarium crown and root rot of tomato caused by $F$. oxysporum $\mathrm{f}$. sp. radicis-lycopersici $(21,23)$. In some areas, there may be issues that preclude the soil injection of 1,3-dichloropropene plus chloropicrin because of the proximity of private dwellings or the impracticality of wearing protective apparel because of high

Table 3. Greenhouse and field reaction of China aster cultivars to Fusarium wilt

\begin{tabular}{|c|c|c|c|c|c|c|c|c|}
\hline \multirow[b]{3}{*}{ Cultivar $(\text { Co. })^{b}$} & \multicolumn{4}{|c|}{ Greenhouse } & \multicolumn{4}{|c|}{ CT field } \\
\hline & \multicolumn{2}{|c|}{ Disease ratinga } & \multicolumn{2}{|c|}{ Dry weights (g) } & \multicolumn{2}{|c|}{ Disease ratinga } & \multicolumn{2}{|c|}{ Harvested flowers } \\
\hline & Control & Infested & Control & Infested & Control & Infested & Control & Infested \\
\hline Aster Composition (SS) & $\ldots^{\mathrm{c}}$ & $\ldots$ & $\ldots$ & $\ldots$ & 1.0 & $1.0 \mathrm{NS}^{\mathrm{d}}$ & 11.8 & $4.10 \mathrm{NS}$ \\
\hline Aster Sandy Mix (SS) & $\ldots$ & $\ldots$ & $\ldots$ & $\ldots$ & 1.0 & $1.4 \mathrm{NS}$ & 27.0 & $34.8 \mathrm{NS}$ \\
\hline Bouquet Powderpuff Mix (HS) & 1.0 & $1.3 \mathrm{NS}$ & 1.61 & $1.57 \mathrm{NS}$ & 1.0 & $1.9 \mathrm{NS}$ & 31.8 & $32.0 \mathrm{NS}$ \\
\hline Astoria Mix (HS) & 1.6 & $2.1 \mathrm{NS}$ & 0.94 & $0.91 \mathrm{NS}$ & 1.4 & $2.3 \mathrm{NS}$ & 31.3 & $23.8 \mathrm{NS}$ \\
\hline Astoria Mix (SS) & 1.0 & $2.0 \mathrm{NS}$ & 1.65 & $1.64 \mathrm{NS}$ & 1.4 & $1.5 \mathrm{NS}$ & 35.0 & $25.0 \mathrm{NS}$ \\
\hline Finest Mixed (SS) & 1.0 & $1.6 \mathrm{NS}$ & 1.38 & $1.56 \mathrm{NS}$ & 1.8 & $3.0 \mathrm{NS}$ & 28.5 & $11.8 *$ \\
\hline Matsumoto Salmon (SS) & 1.0 & $3.1 * *$ & 0.84 & $0.63 \mathrm{NS}$ & 1.4 & $3.0 \mathrm{NS}$ & 27.3 & $0.8 * * *$ \\
\hline Matsumoto Formula Mix. (JSS) & 1.0 & $1.8 \mathrm{NS}$ & 1.00 & $0.84 \mathrm{NS}$ & 1.3 & $3.1 * *$ & 23.5 & $22.5 \mathrm{NS}$ \\
\hline SC* Serenade Mix (JSS) & 1.0 & $2.0 \mathrm{NS}$ & 0.57 & $0.52 \mathrm{NS}$ & 2.0 & $4.1 *$ & 30.3 & $0.8 * * *$ \\
\hline Starlight Mix (SS) & 1.0 & $2.5 *$ & 0.58 & $0.41 \mathrm{NS}$ & 1.0 & $5.0 * * *$ & 39.3 & $3.8 * * *$ \\
\hline Powderpuff (SSC) & 1.1 & $2.6 *$ & 0.90 & $0.75 \mathrm{NS}$ & 1.0 & $2.6 * * *$ & 21.3 & $20.0 \mathrm{NS}$ \\
\hline Matsumoto Yellow (SS) & 1.0 & $2.6 *$ & 1.38 & $1.45 \mathrm{NS}$ & 1.2 & $2.1 * *$ & 15.3 & $20.0 \mathrm{NS}$ \\
\hline Fan Mix Aster (HS) & 1.1 & $2.8 *$ & 1.48 & $0.96 \mathrm{NS}$ & 1.8 & $3.5 * *$ & 23.0 & $18.0 *$ \\
\hline Opus (JSS) & 1.0 & $4.0 * *$ & 0.56 & $0.47 \mathrm{NS}$ & 1.4 & $4.5 * * *$ & 34.0 & $5.5 * *$ \\
\hline Aster Spider Chrysanthemum Mixed (TM) & 1.0 & $2.6 *$ & 0.43 & $0.26 \mathrm{NS}$ & $\ldots$ & $\ldots$ & $\ldots$ & $\ldots$ \\
\hline Benary's Princess Formula Mix (JSS) & 1.0 & $1.5 \mathrm{NS}$ & 0.89 & $0.62 \mathrm{NS}$ & $\ldots$ & $\ldots$ & $\ldots$ & $\ldots$ \\
\hline Tiger Paws Mixed (SS) & 1.0 & $3.4 * *$ & 0.87 & $0.45 \mathrm{NS}$ & 1.6 & $4.8 * * *$ & 18.3 & $2.5 * *$ \\
\hline Aster Serenade Mix (SS) & $\ldots$ & $\ldots$ & $\ldots$ & $\ldots$ & 1.2 & $4.3 * * *$ & 10.8 & $7.7 \mathrm{NS}$ \\
\hline Aster Early Ostrich Plume (TM) & 2.3 & $3.3 \mathrm{NS}$ & 0.58 & $0.26 \mathrm{NS}$ & $\ldots$ & $\ldots$ & $\ldots$ & $\ldots$ \\
\hline Massagno mixed (SS) & 1.0 & $3.4 * *$ & 0.82 & $0.24 \mathrm{NS}$ & $\ldots$ & $\ldots$ & $\ldots$ & $\ldots$ \\
\hline Aster Powderpuffs Mixed colors (CCH). & 2.2 & $3.9 * *$ & 0.24 & $0.12 \mathrm{NS}$ & $\ldots$ & $\ldots$ & $\ldots$ & $\ldots$ \\
\hline Dwarf Queen White (SS). & 1.0 & $4.1 * *$ & 0.54 & $0.16 \mathrm{NS}$ & $\ldots$ & $\ldots$ & $\ldots$ & $\ldots$ \\
\hline Unicum mixed aster (JSS) & 1.0 & $4.2 * *$ & 0.73 & $0.45 \mathrm{NS}$ & $\ldots$ & $\ldots$ & $\ldots$ & $\ldots$ \\
\hline Pot N' Patio Mix (SS) & 1.0 & $4.2 * *$ & 0.80 & $0.18 *$ & $\ldots$ & $\ldots$ & $\ldots$ & $\ldots$ \\
\hline Unicum mix (SS) & 1.2 & $4.3 * *$ & 0.88 & $0.12 *$ & $\ldots$ & $\ldots$ & $\ldots$ & $\ldots$ \\
\hline Giant Ray Mid Blue Aster (HS) & 1.0 & $4.3 * *$ & 1.42 & $0.25 * *$ & $\ldots$ & $\ldots$ & $\ldots$ & $\ldots$ \\
\hline Aster Crego Mixed colors $(\mathrm{CCH})$ & 1.0 & $4.3 * *$ & 0.60 & $0.18 \mathrm{NS}$ & $\ldots$ & $\ldots$ & $\ldots$ & $\ldots$ \\
\hline Aster Blue Ribbon (TM) & 1.0 & $4.4 * *$ & 0.92 & $0.13 *$ & $\ldots$ & $\ldots$ & $\ldots$ & $\ldots$ \\
\hline Crego Finest Mixed (SS) & 1.0 & $4.6 * *$ & 0.97 & $0.13 *$ & $\ldots$ & $\ldots$ & $\ldots$ & $\ldots$ \\
\hline Giant Ray Fiery Red (HS) & 1.0 & $4.6 * *$ & 1.66 & $0.31 * *$ & $\ldots$ & $\ldots$ & $\ldots$ & $\ldots$ \\
\hline Irresistible Mix (JSS) & 1.0 & $4.7 * *$ & 0.83 & $0.11 *$ & $\ldots$ & $\ldots$ & $\ldots$ & $\ldots$ \\
\hline Rubens Improved Pompon mix (JSS) & 1.0 & $4.8 * *$ & 0.81 & $0.03 *$ & $\ldots$ & $\ldots$ & $\ldots$ & $\ldots$ \\
\hline Aster Duchess Mixed (TM) & 1.0 & $4.8 * *$ & 0.86 & $0.10 *$ & $\ldots$ & $\ldots$ & $\ldots$ & $\ldots$ \\
\hline Dwarf Queen mixed (SS) & 1.0 & $4.8 * *$ & 1.15 & $0.05 * *$ & $\ldots$ & $\ldots$ & $\ldots$ & $\ldots$ \\
\hline Mini-lady Mixed (SS) & 1.0 & $4.8 * *$ & 0.94 & $0.11 *$ & $\ldots$ & $\ldots$ & $\ldots$ & $\ldots$ \\
\hline Aster Lilliput Blue Moon (TM) & 1.0 & $4.9 * *$ & 0.90 & $0.03 *$ & $\ldots$ & $\ldots$ & $\ldots$ & $\ldots$ \\
\hline Aster Milady Mixed (TM) & 1.0 & $4.9 * *$ & 0.70 & $0.04 *$ & $\ldots$ & $\ldots$ & $\ldots$ & $\ldots$ \\
\hline Aster Red Ribbon (TM) & 2.3 & $5.0 * *$ & 0.23 & $0.00 *$ & $\ldots$ & $\ldots$ & $\ldots$ & $\ldots$ \\
\hline Asteroid Mix (SS) & 1.1 & $5.0 * *$ & 0.71 & $0.00 *$ & $\ldots$ & $\ldots$ & $\ldots$ & $\ldots$ \\
\hline Asteroid Rose (SS). & 1.0 & $5.0 * *$ & 0.74 & $0.00 *$ & $\ldots$ & $\ldots$ & $\ldots$ & $\ldots$ \\
\hline Asteroid Light Blue (SS) & 1.0 & $5.0 * *$ & 0.73 & $0.00 *$ & $\ldots$ & $\ldots$ & $\ldots$ & $\ldots$ \\
\hline Pot N’ Patio Pink (SS) & 1.0 & $5.0 * *$ & 1.02 & $0.00 * *$ & $\ldots$ & $\ldots$ & $\ldots$ & $\ldots$ \\
\hline Pot N’ Patio White (SS) & 1.0 & $5.0 * *$ & 0.67 & $0.00 *$ & $\ldots$ & $\ldots$ & $\ldots$ & $\ldots$ \\
\hline Duchesse Formula Mix (SS). & 1.0 & $5.0 * *$ & 1.26 & $0.00 * *$ & $\ldots$ & $\ldots$ & $\ldots$ & $\ldots$ \\
\hline Mini-lady Blue (SS) & 1.0 & $5.0 * *$ & 1.02 & $0.00 * *$ & $\ldots$ & $\ldots$ & $\ldots$ & $\ldots$ \\
\hline
\end{tabular}

a Disease ratings in the field and greenhouse were based on a scale of 1 to 5 where $1=$ no disease, $2=$ slight yellowing, $3=$ yellowing and slight wilt, $4=$ severe wilt, or $5=$ dead or near death.

b Seed distribution Companies: SSC = Sheffield's Seed Co, Locke, NY; JSS = Johnny's Selected Seed, Winslow, ME; TM = Thompson and Morgan, Jackson, NJ; SS = Stokes Seed Co., Buffalo, NY; HS = Harris Seeds, Rochester, NY; CH = Chas C. Hart Seed Co., Wethersfield, CT.

c Not done.

${ }^{\mathrm{d}} \mathrm{NS}, *, * *$, and $* * *$ refer to Not Significant and Significant at $P<0.05, P<0.01$, and $P<0.001$, respectively, when compared to their respective controls; values from greenhouse trials represent the means of nine pots from two greenhouse trials; values from field studies represent the means of eight plots (five plants/plot) from field plots in Hamden, CT and Windsor, CT. 
temperatures. In those cases, it would be advisable to substitute the Inline formulation of the fumigant (Dow Agro Sciences LLC, Indianapolis, IN), which can be applied to the soil through irrigation tape covered by plastic mulch, thus avoiding possible worker exposure and drift. Metam sodium and 1,3-dichloropropene plus chloropicrin are currently labeled for use in cut-flower production in Florida. Two other methyl bromide alternatives, idomethane plus chloropicrin and dimethyl disulfide plus chloropicrin, are under long-term evaluation for delphinium production at a cutflower facility in southeastern Florida (30).

The third objective of this research was to assess the level of wilt resistance in commercial lines. We concluded that highly resistant cultivars were not found, but four cultivars were identified that had moderate resistance to the disease. One (Astoria Mix) was obtained from two seed distribution companies and, as expected, behaved similarly since the seed probably came from the same source. There was fairly good agreement between the greenhouse and field assays, but performance under field conditions was more reliable as it provided data on actual flower yield. On the basis of our studies, wilt resistance was not strictly associated with a particular phenotype, but it was noted that the Matsumoto series tended to have more resistance in many of their cultivars than in other series. With the exception of 'Matsumoto Light Blue,' the generally low incidences of Fusarium wilt in Matsumoto cultivars observed in the Fusarium wilt epidemic that occurred in the Florida production facility tends to support this hypothesis. Since most of the more resistant cultivars were actually mixes of different lines, it seems promising that highly resistant lines in these mixes might be identified and used as individual lines to serve in future breeding programs. However, the ability of the pathogen to overcome resistance may be rapid, making host resistance a short-term management strategy.

A large evaluation of wilt resistance in China aster cultivars was done by Nečas and Kobza (24), who placed up to 63 cultivars into three categories: resistant, moderately resistant, and susceptible. They found the 'Madeleine' series, which is phenotypically similar to the original botanical species $(C$. chinensis), to be the most resistant to Fusarium wilt. Although those particular lines were not examined in the current study, four cultivars were examined in both studies: 'Matsumoto Salmon,' 'Matsumoto Formula Mix,' 'Matsumoto Yellow,' and 'Fan Mix.' The two studies agree that the Matsumoto cultivars have moderate resistance to wilt, but we found 'Fan Mix' to be susceptible in the current study. However, the ratings by Nečas and Kobza (24) were based on plant mortality as opposed to disease severity, so these differences in methods may explain the conflicting results. Another possible cause of the divergent results is their use of a different isolate of F. oxysporum f. sp. callistephi.

Historically, host resistance has always been the most successful strategy for managing Fusarium wilt (9). However, the rapid emergence of new strains has thwarted efforts to manage the disease with resistant germplasm. Our findings suggest that most New England strains are closely related and for the immediate future may be suppressed using resistant cultivars. Growers are still encouraged to practice seed sanitation to prevent the pathogen from being introduced. Additional strategies such as fertilization (14) need to be explored to augment current disease management.

\section{Acknowledgments}

We thank Joan Bravo, Peter Thiel, Teresa Seijo, Megan Gilbert, Amanda Bisson, Raghuwinder Singh, and R. McSorley for laboratory assistance, and Kristen Evancha for field assistance. We thank the following seed companies for donating seeds: Chas. C. Hart Seed Co. (Wethersfield, CT), Harris Seed Co. (Rochester, NY), Johnny's Selected Seed (Winslow, ME), Stokes Seed Co. (Buffalo, NY), Sheffield's Seed Co. (Locke, NY), and Thompson and Morgan (Jackson, NJ). We also thank the American Floral Endowment for partial funding of this research.

\section{Literature Cited}

1. Anonymous. 2000. The Montreal Protocol on Substances that Deplete the Ozone Layer. http://ozone.unep.org/pdfs/Montreal-Protocol2000.pdf

2. Anonymous. 2000. Statistical Data on Horticultural Crops in Karnataka
State, by Department of Horticulture, Lalbagh, Bangalore.

3. Baker, K. F. 1953. Fusarium wilt of China aster. USDA Yearb. 1953:572577.

4. Beach, W. S. 1918. The Fusarium wilt of China aster. Mich. Acad. Sci. Rep. 20:282-307.

5. Britton, W. E. 1899. The stem rot disease. Conn. Agric. Exp. Stn. Annu Rep. 23:236-238

6. Correll, J. C., Klittich, C. J. R., and Leslie, J. F. 1987. Nitrate nonutilizing mutants of Fusarium oxysporum and their use in vegetative compatibility tests. Phytopathology 77:1640-1646

7. Dhingra, O. D., Sinclair, J. B. 1985. Basic Plant Pathology Methods. CRC Press, Boca Raton, FL.

8. Elmer, W. H. 2002. Seeds as vehicles for pathogen importation. Biol. Invasions 3:263-271.

9. Elmer, W. H. 2012. Cultural Management. Pages 67-74 in: Fusarium Wilts of Greenhouse Vegetable and Ornamental Crops. A. Garibaldi, J. Katan, and M. Lodovica Gullino, eds. American Phytopathological Society, St. Paul, MN.

10. Elmer, W. H., and Stephens, C. T. 1988. Comparison of technique for eliminating contaminants from asparagus seeds. HortScience 23:1031-1032.

11. Galloway, B. T. 1896. Disease of China Asters. Am. Gar. 17:518.

12. Han, F. 2010. The effect of microwave treatment on germination, vigour and health of China aster (Callistephus chinensis Nees.) seeds. J. Agric. Sci. 2:201-210.

13. Jackson, A. B. 1927. The Fusarium wilt of China asters. Sci. Agric. 7:233247.

14. Jones, J. P., Engelhard, A. W., and Woltz, S. S. 1989. Management of Fusarium wilt of vegetables and ornamentals by macro- and microelement nutrition. Pages 18-32 in: Soilborne Plant Pathogens: Management of Diseases with Macro- and Microelements. A. W. Engelhard, ed. American Phytopathological Society, St. Paul, MN.

15. Jones, L. R., and Riker, R. S. 1931. Wisconsin studies on aster diseases and their control. Wisc. Agric. Exp. Stn. Res. Bull. 111:1-39.

16. Katan, T., Shlevin, E., and Katan, J. 1997. Sporulation of Fusarium oxysporum f. sp. lycopersici on stem surfaces of tomato plants and aerial dissemination of inoculum. Phytopathology 87:712-719.

17. Komada, H. 1975. Development of selective medium for quantitative isolation of Fusarium oxysporum from natural soil. Rev. Plant Prot. Res. 8:114-124.

18. Leslie, J. F., and Summerell, B. A. 2006. The Fusarium Laboratory Manual Blackwell Publishing, Ames, IA.

19. McGovern, R. J., Elmer, W. H., Gesier, D. M., and Harbugh, B. 2004. Fighting Fusarium: Case II - Fusarium stem rot of lisianthus. Greenhouse Grower 22:146-150.

20. McGovern, R. J., Harbaugh, B. K., and Polston, J. E. 1997. Severe outbreaks of Fusarium crown and stem rot in lisianthus in Florida. (Abstr.) Phytopathology 87:S64.

21. McGovern, R. J., and Vavrina, C. S. 2004. Reduction of Fusarium crown and root rot in tomato by 1,3-dichloropropene plus chloropicrin in Southwest Florida. Proc. Soil Crop Sci. 63:96-99.

22. McGovern, R. J., Vavrina, C. S., and McKay, L. A. 1993. Effect of transplant tray and tomato cultivar on the incidence of Fusarium crown and root rot in tomato transplants. Proc. Fla. State Hortic. Soc. 106:173-175.

23. McGovern, R. J., Vavrina, C. S., Noling, J. W., Datnoff, L. D., and Yonce, H. D. 1998. Evaluation of different application methods of metam sodium for management of Fusarium crown and root rot in tomato in southwest Florida. Plant Dis. 82:919-923.

24. Nečas, T., and Kobza, F. 2008. Resistance of Chinese asters (Callistephus chinensis Nees.) to Fusarium wilts (Fusarium oxysporum f. sp. callistephi (Beach) Snyder and Hansen) evaluated using artificially inoculations. Hortic. Sci. (Prague) 33(4):151-161.

25. Orlicz-Luthardt, A. 1998. On the transfer of Fusarium wilt by seeds in China aster. Seed Sci. Technol. 26:67-76.

26. Persiel, F., and Lein, L. 1989 Investigations on the resistance of China asters (Callistephus chinensis) to Fusarium oxysporum f. sp. callistephi. Z. Pflanzenkrankh. Pflanzenschutz. 96:47-59.

27. Rekah, Y., Shtienberg, D., and Katan, J. 2000. Disease development following infection of tomato and basil foliage by airborne conidia of the pathogen Fusarium oxysporum f. sp. radicis-lycopersici and F. oxysporum f. sp. basilici. Phytopathology 90:1322-1329.

28. Riker, R. S. 1936. Fusarium lateritium v. fructigenum in relation to wilt of China aster. (Abstr.) Phytopathology 26:1085-1086.

29. Riker, R. S., and Jones, L. R. 1935. Fusarium strains in relation to wilt of China aster. Phytopathology 25:733-747.

30. Rosskopf, E. N., Kokalis-Burelle, N., Nissen, O., Hartmann, R., Skvarch, E., and McSorley, R. 2010. Area-wide demonstration of chemical alternatives to methyl bromide for Florida ornamentals. 2010. Annu. Int. Res Conf. Methyl Bromide Alternatives Emissions Reductions. Pap. no. 82:1-4.

31. Snyder, W. C., and Hansen, H. N. 1940. The species concept in Fusarium. Am. J. Bot. 27:64-67.

32. Stone, G. E., and Smith, R. E. 1902. Aster stem rot. In: The Report of the Botanist. MA (Hatch) Annu. Rep. 68-69.

33. USEPA. 2011. Protection of Stratospheric Ozone: The 2011 Critical Use Exemption From the Phaseout of Methyl Bromide. Federal Register Vol. 76(190):60736-60748. 